\title{
Sensitivity evaluation of Krakowiec clay based on time-dependent behavior
}

https://doi.org/10.1515/geo-2018-0057

Received May 17, 2018; accepted Aug 20, 2018

\begin{abstract}
Time resistance of soil structure in oedometer IL (Incremental Loading) tests was defined by Janbu as specific dependence between load and development of strain during consolidation process. A number of laboratory tests have been conducted in order to study the time dependent behaviour of the natural and remoulded clay, thereby providing sensitivity evaluation. The soil sensitivity framework was applied to represent the effect of structure and stress dependency on the time resistance number. For this purpose, the creep behavior of structured and remolded clay during consolidation were compared and the initial amount of bonding (structure) was determined as well. In this study, the initial amount of bonding was defined through the intrinsic time resistance number and lowest measured time resistance number determined by the IL oedometer test conducted on intact (undisturbed) sample. In case of the Krakowiec clay, it was found that the time resistance number varies with effective stress level. The investigated clay indicated medium sensitivity, which is in great agreement with previous reports on the sensitivity of the Krakowiec clay.
\end{abstract}

Keywords: clay, consolidation, creep, time-dependent, time resistance, sensitivity

\section{Introduction}

Conceptual models reflecting the soil behaviour under load in terms of mechanical aspects are increasingly used in geotechnical practice. In order to define them, sets of mechanical properties are assumed, which are obtained

\footnotetext{
*Corresponding Author: Bartłomiej Olek: Tadeusz Kościuszko University of Technology, Department of Structural Mechanics, Krakow; Email: bartlomolek@gmail.com

Paweł Dobak: University of Warsaw, Department of Geology, Warsaw

Grażyna Gaszyńska-Freiwald: Tadeusz Kościuszko University of Technology, Department of Environmental Engineering, Krakow
}

by means of mathematical calibration procedures in relation to experimental results. An important factor of soil behaviour is the nature of their structure. Therefore, a full mechanical description of the response of a clay soil to a given load should be based on a comparison of the properties obtained from tests conducted on high quality undisturbed samples (naturally structured) and remolded samples (pastes). Depending on the sedimentation environment, load history, degree of cementation, soils are characterised by an internal system of particles and bonds between them, so-called natural skeleton. Such soil often shows anisotropic properties, which affects the behaviour under loading [1]. Yielding behaviour of natural soils after reaching the preconsolidation pressure is usually associated with destructuration (reconstruction of their original structure). Equivalently in laboratory soil tests, this process is determined at yielding stress $\sigma_{v y}$. Soil destructuration results from disturbances in the original soil structure, which can be characterized as a gradual destruction of bonds between particles during plastic deformation. Bonding encompasses all forces occurring between particles that do not occur as a result of pure friction between them [2].

The quantitative synthetic indicator of structural bonding that can be lost as a result of the destructuration process can be presented numerically as a single state variable $x[3]$. The state variable $x$ can be treated as a measure of "structural sensitivity". When $x=0$, it means a complete loss of the original structure. Changes in the state parameter $x$ depend on the state of strain (one-dimensional or tridimensional) and are expressed as plastic volumetric deformations as well as increments of deviatoric strains [4]. It should be noted that the bonds are not immediately reduced as a result of yielding but are related to the development of strains [5]. Soil susceptibility to the degradation of interparticle bonds and the changes in structure resulting from this feature are associated with structural sensitivity.

The aim of the article was the assessment of the sensitivity of Krakowiec clay from Chmielow, which was revealed as result of uniaxial consolidation, observed in oedemeter test. In this study, structural sensitivity is related to the time-dependent response of the soil under 


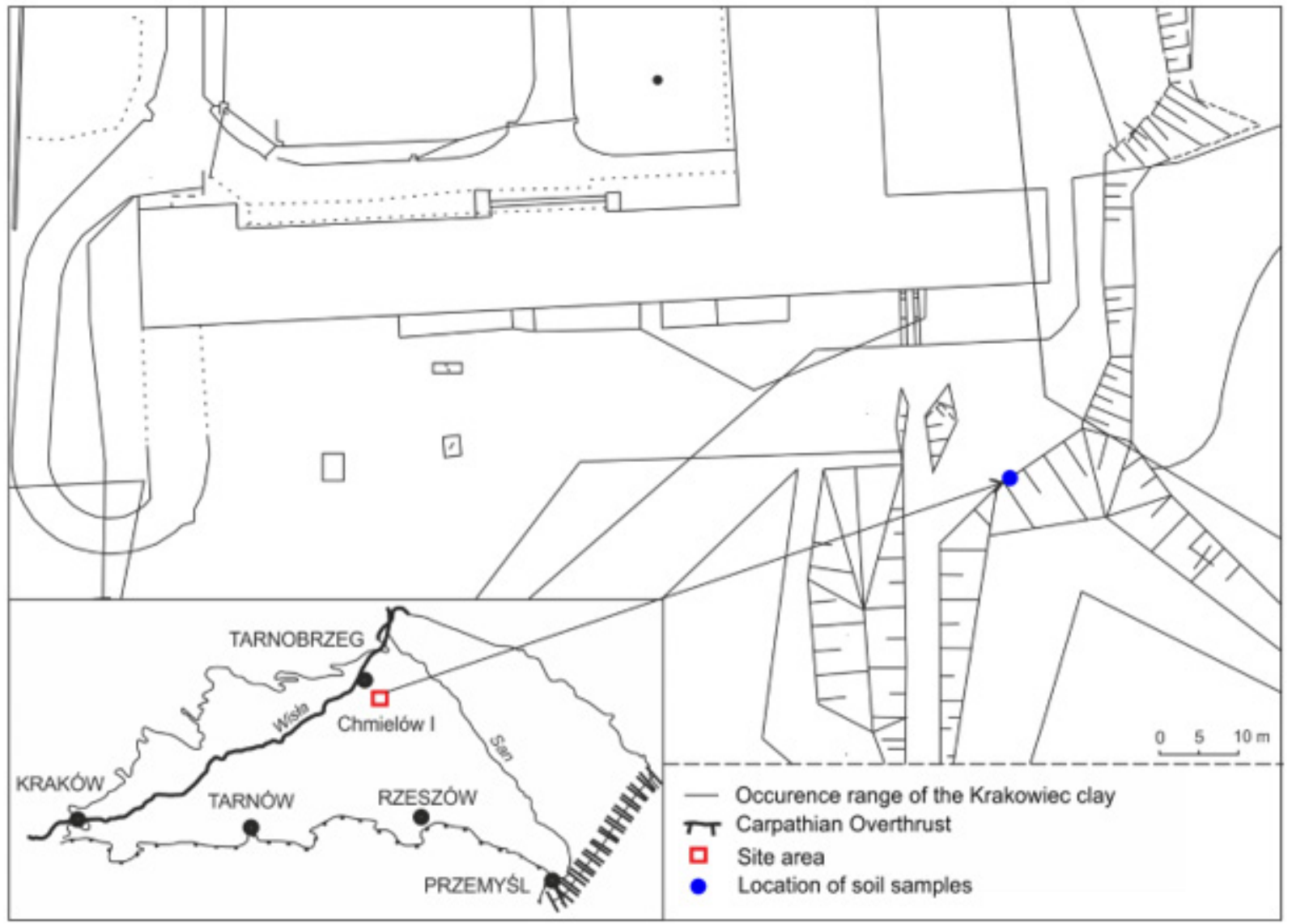

Figure 1: Location of soil sampling.

Table 1: Physical parameters of soils analysed in the present study.

\begin{tabular}{ccccccccc}
\hline Soil & \multicolumn{3}{c}{ Particle size } & \multicolumn{2}{c}{ Atterberg limits } & Plasticity & Organic & Specific \\
& $\begin{array}{c}\text { Sand } \\
{[\%]}\end{array}$ & $\begin{array}{c}\text { Silt } \\
{[\%]}\end{array}$ & $\begin{array}{c}\text { Clay } \\
\text { [\%] }\end{array}$ & $\begin{array}{c}\text { Liquid limit } \\
{[\%]}\end{array}$ & $\begin{array}{c}\text { Plastic limit } \\
{[\%]}\end{array}$ & $\begin{array}{c}\text { index } I_{p} \\
{[\%]}\end{array}$ & $\begin{array}{c}\text { content } I_{\dot{z}} \\
{[\%]}\end{array}$ & $\begin{array}{c}\text { gravity } \mathrm{G}_{s} \\
{[-]}\end{array}$ \\
\hline $\begin{array}{c}\text { Krakowiec } \\
\text { clay }\end{array}$ & 14 & 48 & 38 & 65.02 & 24.60 & 40.42 & - & 2.72 \\
\hline
\end{tabular}

load. For this purpose, we used a model that accounts creep and it was based on the time resistance concept [6].

\section{Materials and methods}

\subsection{Study area}

To validate the application of time-dependent behavior assessed by the time resistance concept for the evaluation of sensitivity, an extensive testing programme was conducted. The chosen test site was the "Chmielów I" clay deposit in Chmielów village (Figure 1). Geographically, the deposit area is located in the northern part of the ForeCarpathian Basin, in Sandomierz Lowland, Poland on the right bank of the Vistula river.

\subsection{Material overview}

The material for the laboratory analysis was taken from the clay formation of Miocene age (Sarmatian stage) of the Fore-Carpathian Basin. These soils are represented by gray or slightly green clays, locally with inserts of sandy layers. The physical properties of soil used in the study are listed in the Table 1 . The time dependent behaviour of reconstituted Krakowiec clay as well as the intact clay have 
been in the focus of interest. Reconstituted samples were obtained by remolding the natural Krakowiec clay material. The aim of the remolding procedure is to erase the initial soil structure. Remolding was performed by mixing the natural Krakowiec clay material with water to produce slurry having water content approaching the liquid limit (wn $\approx \mathrm{LL}$ ). To obtain clear insight into time dependent behaviour and creep characteristics of Krakowiec clay we performed incrementally loaded (IL) oedometer tests. The consolidation cell used a fixed-type ring setup with single drainage at the top of the specimen.

\subsection{Time dependent behavior of cohesive soils}

Since the late 1940s, the interest of many research centres on time-dependent mechanical properties of soil has increased. The determination of a delay in deformation as a function of time was of fundamental importance for the description of these properties. Bjerrum [7], observing long-term settlements of foundations, suggested distinguishing instant and delayed compression and introduced the so-called time lines (isochrones) (Figure 2) to model the reduced creep rates resulting from changes in loading time. Instant compression occurs simultaneously with an increase of effective stresses and reduces the pore space at which the structure is able to transfer the load completely. Delayed compression represents the reduction of the pore space at which the structure completely transfers the load. Delayed compression includes both the stages of consolidation: primary and secondary consolidation. Their course can be presented using the concept of fixed time lines (isochrones) (Figure 2). The $\mathrm{AB}$ line represents "immediate" compression during a conventional oedometer test, while $\mathrm{BC}$ line shows a change in the porosity or strain index at constant effective stress due to secondary consolidation. If the soil at point $\mathrm{C}$ is loaded, the obtained new CD curve, with a clear effect of apparent preconsolidation pressure, will represent instant compression. The CE curve represents the behaviour corresponding to the time-dependent compression. The course of the time line in terms of Bjerrum is directly related to the creep hypothesis B, which was formally proposed by Ladd et al. [8]. The hypothesis B concerns the occurrence of creep during primary compression and is based on the assumption that the void ratio $e_{E O P}$ or strain at the end of the primary compression $\epsilon_{E O P}$ increases and the apparent preconsolidation pressure $\sigma_{c}^{\prime}$ decreases together with the duration of the primary compression.

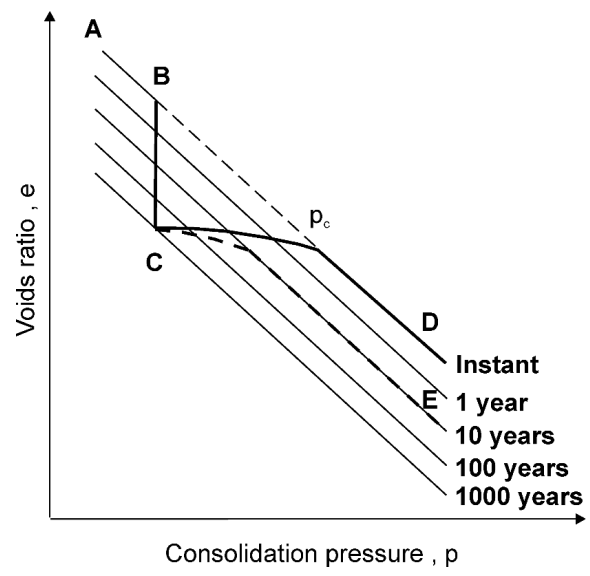

Figure 2: Bjerrum's isotaches model for incremental 1-D loading. Series of parallel time lines describing the compressibility and shear strength of clay, which shows delayed consolidation.

The justification for B hypothesis is the occurrence of delayed deformation during the entire consolidation process $[6,9-11]$. The creep of the soil skeleton is often considered as secondary consolidation. However, this view is not entirely correct. The distinctions between these two concepts were made by Tavenas et al. [12] who recognised that secondary consolidation was caused only by creeping. However, creep may also occur before the secondary consolidation stage. Ex definitione creep is a process when soil deformation in a function of time is observed and creep rate is controlled by viscous resistance. Using the concept of time resistance proposed by Janbu (1969) and successively developed in later works [13-15], the occurrence of the creeping factor both in the primary and secondary consolidation stage was also observed and presented in the analysis.

\subsection{Time resistance concept}

The analysis of the course of creep resistance changes [6] allows to characterize the stress-dependent and timedependent behaviour of the compressed soil. Graphically, the time resistance of soil creep $R$ can be expressed as tangent to the time-strain curve at the analyzed point (Figure $3 \mathrm{~A}$ ). Creep time resistance is defined as the time necessary to create a unitary value of relative strain:

$$
R=\frac{d t}{d \varepsilon}=1 / \dot{\varepsilon}
$$

where: $d t$ - increase in time, $d \epsilon$ - change (increase) of strain

For the majority of cohesive soils, time resistance increases together with the progress of consolidation (Figure $3 \mathrm{~B})$. Considering the primary consolidation phase, the 


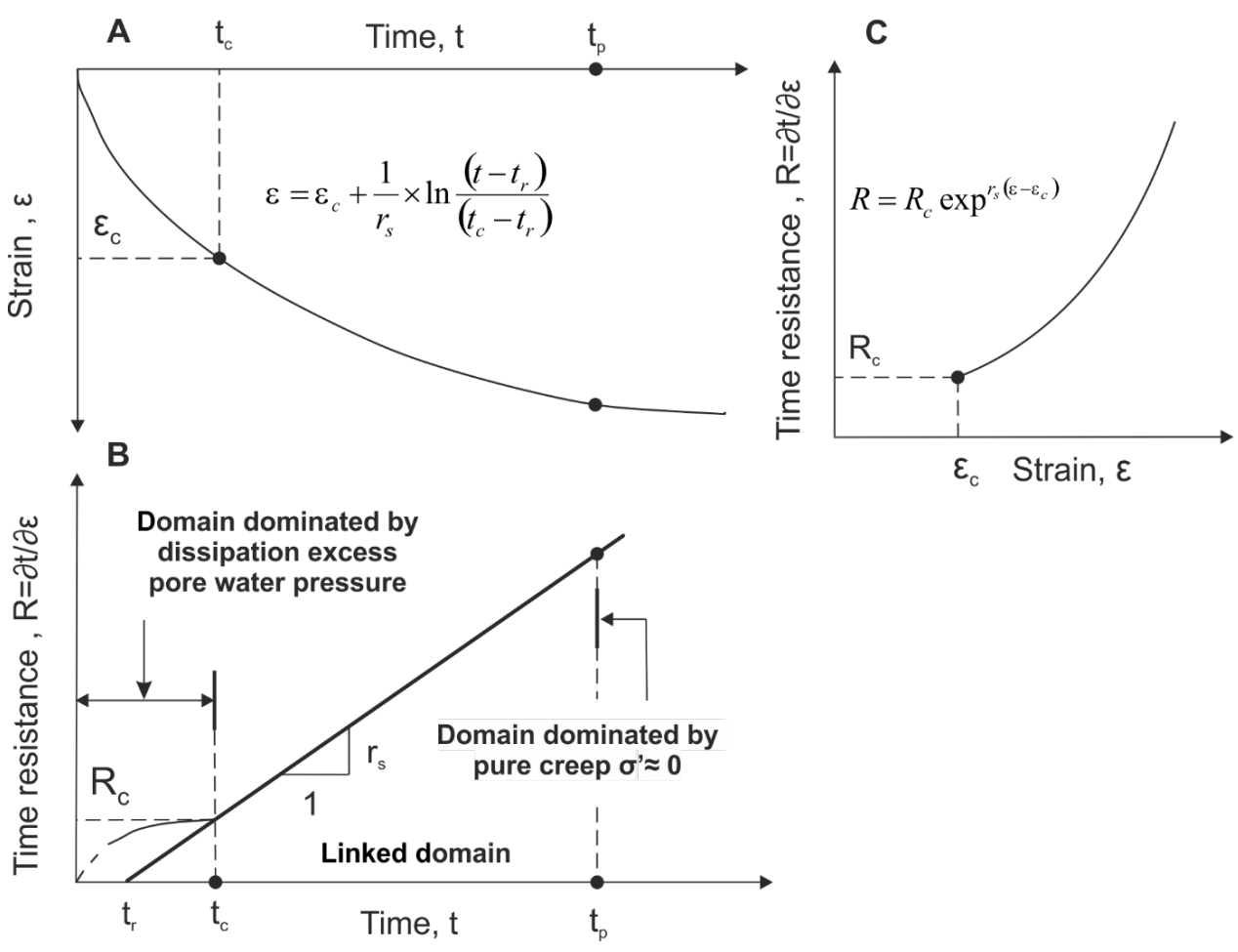

Figure 3: Time resistance concept: A) Typical strain - time curve from oedometer test; B) Time resistance as a function of time with key parameters for modelling creep behaviour of soil; C) Time resistance as a function of strain for one load step in an oedometer ( $\sigma_{v}^{\prime}=$ constant).

$R-t$ curve has a curvilinear shape at an early stage, changing in a further stage after reaching the time $t_{p}$ into a quasilinear relationship, which should be associated with creep of the soil skeleton. Experiments show [16, 17] that extrapolation of a straight line to a horizontal timeline allows to determine the value of time $t_{r}$, which is usually much lower than the duration of the primary consolidation phase, $t_{p}$. Based on the $\mathrm{R}$ - $\mathrm{t}$ curve, three zones can be divided. Initial zone represented by a second degree of parabola, corresponding to primary consolidation for time $\mathrm{t} \leq t_{c}$, transitional zone for time $t_{c} \leq t \leq t_{p}$ and pure creep for time $t \geq t_{p}$. An illustration of this division has been given in Figure 3B. As can be seen after exceeding a certain time $t_{c}$, time resistance increases linearly together with time, thus strain can be expressed as follows:

$$
\varepsilon=\varepsilon_{c}+\frac{1}{r_{s}} \times \ln \frac{\left(t-t_{r}\right)}{\left(t_{c}-t_{r}\right)}
$$

where: $\epsilon_{c}$ is the reference strain for the current effective stress and corresponds to the strain at the end of the primary consolidation, $r_{s}$ is time resistance number (creep number) and $t_{r}$ is reference time

The inclination of the linear relationship between time resistance $R$ and time $t$, at exceeding time $t_{r}$, can be described by the creep number:

$$
r_{s}=\frac{d(\partial t / \partial \varepsilon)}{d t}=\frac{d R}{d t}
$$

Typical values of $r_{s}$ for normally consolidated clays range from 100-500 at natural water content in the range of 30$60 \%$. Assuming that $R=r_{s}\left(t-t_{r}\right)$ and $R_{c}=\mathrm{r}_{s}\left(t_{c}-t_{r}\right)$, the equation (2) can be written in a different way:

$$
\varepsilon=\varepsilon_{c}+\frac{1}{r_{s}} \times \ln \frac{R}{R_{c}}
$$

where: $R_{c}$ is a reference value of the time resistance at the time $t_{c}$ which conforms to the start of secondary consolidation

The reference strain $\epsilon_{c}$ defines the point on the resistance $R$ - $t$ curve from which the equation (4) can be considered as correct (Figure 3C), hence for $\epsilon \geq \epsilon_{c}$ the time resistance $R$ can be presented as a function of the current strain:

$$
R=R_{c} \exp ^{r_{s}\left(\varepsilon-\varepsilon_{c}\right)}
$$

The concept of time resistance has been successfully implemented in many constitutive models accounting for the time-dependent response of the soil to changes in the state of stress. These models, developed from the late 1980s take into account, in addition to creep, structural effects occurring in the soil skeleton, such as bonding and structural degradation (destructuration) $[18,19]$. 


\subsection{Sensitivity framework}

Cotecchia and Chandler [20] presented the sensitivity framework (SF), in which comparisons between parameters referring to intact and remolded soil were made. The aim was to assess the impact of changes in the structure on soil behaviour. The mechanical properties of the soil with a completely disturbed natural structure were defined as intrinsic properties. Structural sensitivity is usually considered as an indicator of the decrease in shear strength of the soil as a result of progressive deformations. Burland [21] related the differences in mechanical characteristics to decreasing strength due to structural disturbances of the natural clay during field sampling.

The sensitivity framework can be applied to show the effect of structure and stress dependency on time resistance number (creep number) in one-dimensional consolidation and compressibility, too. For this purpose, structured and remolded creep behaviour of clay during consolidation were compared, and the initial amount of bonding (structure) was determined as well. In this work the initial amount of bonding was defined through the intrinsic time resistance number and minimum measured time resistance number determined by the IL test conducted on intact (undisturbed) sample. Then, evaluation on the sensitivity of the investigated clay was possible. The sensitivity in this study was related to initial amount of bonding $x_{0}$ :

$$
S_{t}=x_{0}+1
$$

The initial amount of bonding $x_{0}$ was determined using the time resistance concept and intrinsic creep number [13]:

$$
x_{0}=\frac{r_{s i}-r_{s, \min }}{r_{s, \min }}
$$

where: $r_{s i}$ is the intrinsic creep number and $r_{s, \min }$ is the minimum, measured creep number determined by an incremental oedometer test

\section{Results}

\subsection{Evaluation of the time dependent behavior}

The behaviour of the Krakowiec clay under load during the oedometer test was presented using the creep time resistance model. For a comprehensive analysis, it was convenient to track the behaviour related to volumetric creep separately (analysis of the strain-time relationship) and to assess the variability of the parameters together with the consolidation pressure (analysis of creep number-pressure relationship). In this study, only those parts of $\epsilon-R$ and $R-t$ curves were considered that characterized the creep phase. In order to check the predictions of the model, the obtained experimental data were compared with a set of theoretical curves with optional values $\epsilon_{c}, r_{s}, t_{c}, t_{r}, R_{c}$. For this purpose, equations (2) and (5) were used. In Figure 4 an example of the interpretation of the results of the uniaxial consolidation study of a natural sample of Krakowiec clay at a consolidation pressure of $300 \mathrm{kPa}$ was shown.

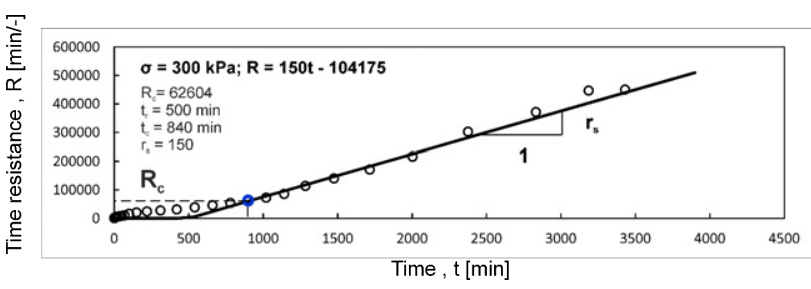

Figure 4: Interpretation of the $\mathrm{R}$ - $\mathrm{t}$ curve for one load step in oedometer test.

Based on the $R$ - $t$ relationship, it could be noticed that the time resistance starts to increase linearly at $R_{c}=$ 62604 minutes and time $t_{c}=840$ minutes. Hence reference strain which corresponds to the time at the end of the primary consolidation consolidation, $\epsilon_{c}$ was 0.039 . The inclination of this part of the graph was characterized by a creep number of $r_{s}=150$. Extrapolating the resistance line towards the parabolic part of the $R-t$ curve referring to the primary consolidation, a $t_{r}$ time of 500 minutes was estimated. The obtained parameters gave the opportunity to check how the time resistance model reflected the experimental course of the creep phase. In Figures $5 \mathrm{~A}$ and $5 \mathrm{~B}$ example curves $\epsilon-t$ and $R-\epsilon$ fitted with the best model

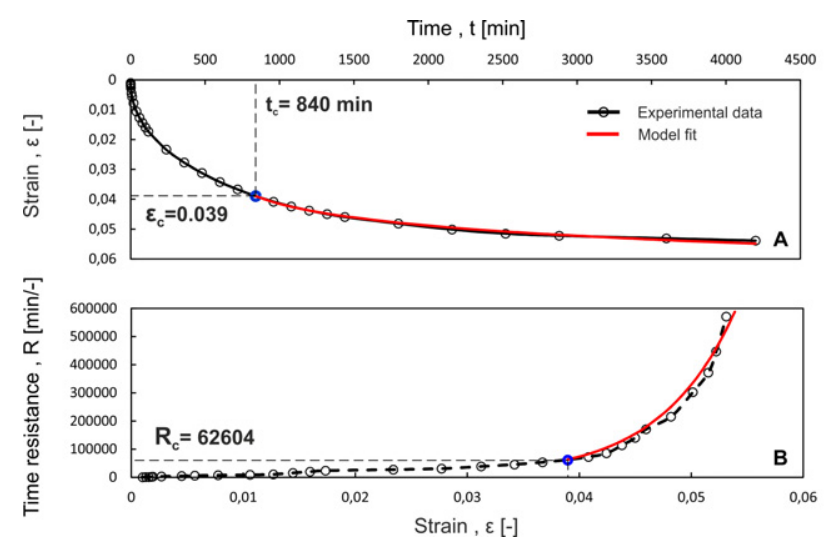

Figure 5: Time dependent behaviour of Krakowiec clay: A) Calculated creep strain in relation to time; B) Calculated time resistance in relation to strain. 
solution characterized by creep number $r_{s}$ and time $t_{r}$ have been presented.

In order to better understand how model parameter $r_{s}$ affects the strain - time curve, additional calculations were made. Also the impact of this parameter on the development and magnitude of deformation was performed. By keeping constant model parameters, it was checked how different values of the creep number affect the characteristics of $\epsilon-t$ in the model. The results of this analysis have been illustrated in Figure 6. The solid line indicates the value of the creep number $r_{s}$, which was obtained on the basis of the interpretation of experimental data. Dashed lines show the results obtained with the change of $r_{s}$ parameter. Due to the fact that the creeping number $r_{s}$ describes the final inclination of the $R-t$ line, the rate of deformation caused by creep could be derived from it. Figure 6 shows the increase of strain associated with the reduction of $r_{s}$ value. Changes in the $r_{s}$ value also affected the final inclination of the $\epsilon-\mathrm{t}$ curve. Summarizing, the higher values of $r_{s}$, the smaller values of creep strain and strain rates.

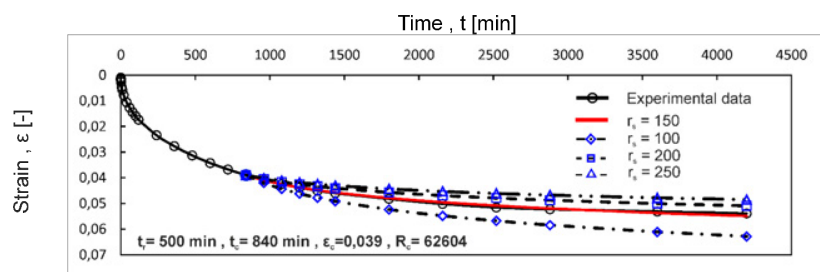

Figure 6: Results from the parametric study of the influence of creep number $r_{s}$ to the behaviour of the time resistance model.

For each loading stage, the $R-t$ relationships were investigated and the parametric modelling discussed above was performed. The nature of the course of the advanced consolidation stage in case of an undisturbed soil sample was dependent on the values of loads applied during the oedometer test. The values of the creep number $r_{s}$ were varied, depending on the relationship to the yielding stress $\sigma_{v y}$, which is determined from $\log \sigma-\epsilon$ graph. In the recompression part of curve $\log \sigma-\epsilon$, where $\sigma<\sigma_{v y}$ large $R$ values were obtained, which gradually decreased when approaching to $\sigma=\sigma_{v y}$. This trend has been illustrated in Figure 7A as a change in the inclination of the graphs at subsequent load steps.

In the virgin part of curve $\log \sigma-\epsilon$, where $\sigma>\sigma r_{s}$ values increased again, gradually reaching the values observed in the samples of disturbed (remoulded) soil samples. The constant values of $r_{s}$ for the remoulded soil are show in Figure 7B as the same inclination of the graphs at
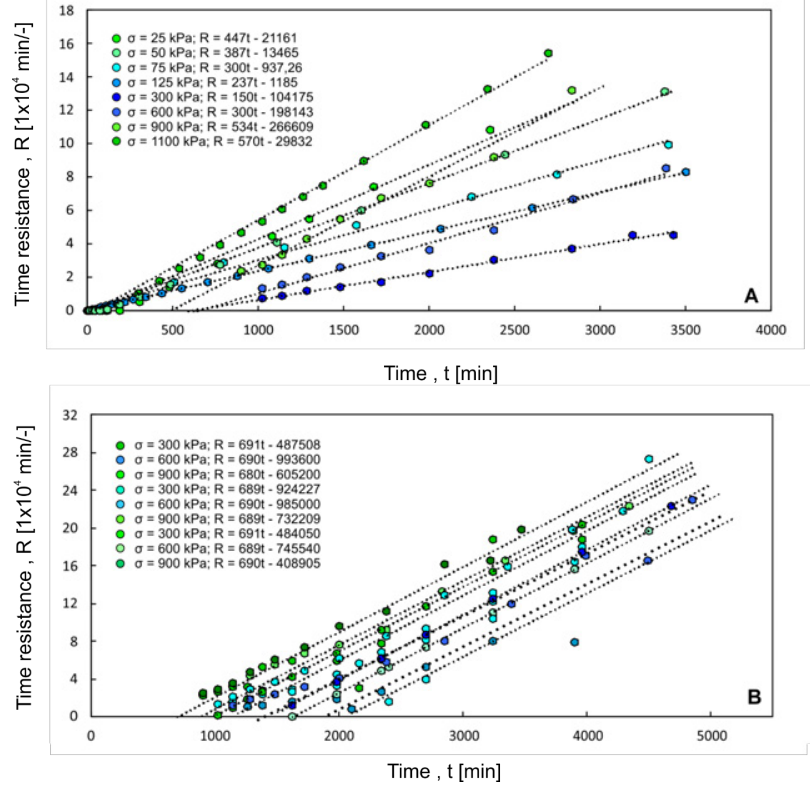

Figure 7: $R$ - t relationships describing time dependent behaviour of Krakowiec Clay for: $A$ - undisturbed samples in wide range of stress; $\mathrm{B}$ - remoulded samples just after exceeding preconsolidation pressure.

subsequent load steps. These indicators should be considered as viscoplastic strain component causing irreversible soil deformation. Therefore, the analysis of creep time resistance considered in relation to the subsequent load steps gave the opportunity to assess directly the preconsolidation state of soil.

\subsection{Stress dependency on creep number and sensitivity}

The creeping phases of 3 remoulded samples showed very similar inclinations, regardless of the applied consolidation stresses in a wide range of values from 300 to $900 \mathrm{kPa}$. In the analyzed remoulded clays from Chmielów, $r_{s}$ values in the stabilized range of $680-691.5$ were obtained. Having the results of consolidation of samples with different structural features resulting from the load history, the initial amount of bonding $x_{0}$ from the equation (7) was determined. This value was then used to assess the sensitivity of the tested soil. Figure 8 shows the relationship between the number of creep and the consolidation stress. The initial amount of bonding $x_{0}$ for the Krakowiec clay, being a scalar state variable, was 3.57.

Using this value in equation (4), on the basis of the time-dependent soil behaviour, the sensitivity $S_{t}=$ 4.57 was obtained. Comparing sensitivity classification of Rosenquist [22] with the results presented in this pa- 
Table 2: Comparison of average physical parameters of selected Miocene Krakowiec clays.

\begin{tabular}{ccccccc}
\hline Location & $\begin{array}{c}\text { State of } \\
\text { soil }\end{array}$ & $\begin{array}{c}\text { Plastic } \\
\text { limit }\end{array}$ & $\begin{array}{c}\text { Liquid } \\
\text { limit }\end{array}$ & $\begin{array}{c}\text { Liquidity } \\
\text { index } I_{L}[-]\end{array}$ & $\begin{array}{c}\text { Sensitivity } \\
\mathrm{S}_{t}[-]\end{array}$ & Reference \\
\hline Chmielów & $\mathrm{tpl}$ & 30.0 & 65.0 & 0.15 & 4.57 & This study \\
Mydlniki (Kraków) & $\mathrm{tpl}$ & 31.0 & 85.0 & 0.13 & 3.13 & Olesiak 2010* $^{*}$ \\
Potaniec & $\mathrm{tpl}$ & 22.0 & 65.4 & 0.13 & 3.22 & Olesiak 2014* \\
Zestawice (Kraków) & $\mathrm{tpl}$ & 28.0 & 89.0 & 0.16 & 2.90 & Pilecka i Zięba 2016 ** \\
\hline
\end{tabular}

Sensitivity determined on the basis of * FVT sounding ${ }^{\star \star}$ SLVT sounding

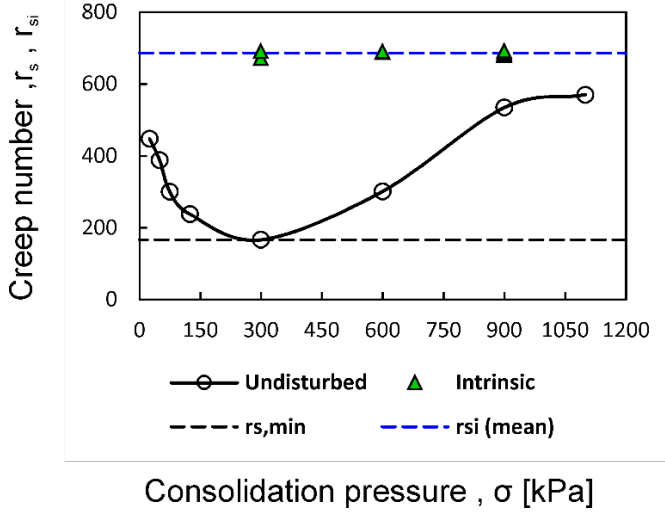

Figure 8: Stress dependency of Krakowiec clay.

per, the obtained value of sensitivity allowed to consider the structural susceptibility to deformation of clays as medium-sensitive. In turn, in the tests of total and residual strength of Krakowiec clays from different regions of Poland, slightly lower values of structural susceptibility were obtained Olesiak [23, 24] and Pilecka and Zięba [25]. This shows similar values of indicators characterizing the structure impact on the consolidation and strength behaviour of Krakowiec clays. Comparative data has been presented in Table 2.

\section{Conclusions}

1. The time resistance $R$ and the resistance number (creep number) $r_{s}$ enable both the assessment of rheological conditions in the course of consolidation and the influence of structural features on the course of deformation.

2. On the basis of model analyses, it can be noted that significant changes in the value of $r_{s}$ parameter (with a curvilinear course of primary consolidation) result from the domination of filtration conditions of the process. The stabilization of the value of the $r_{s}$ parameter indicates an increasing partici- pation of creep before the end of filtration phase of consolidation.

3. The parabolic variability of the $r_{s}$ parameter obtained together with increasing load values with the minimum at preconsolidation pressure value indicates the role of the load history in controlling the soil deformability. The analysis of variability of $r_{s}$ values can be treated as an alternative to the classic methods of preconsolidation characteristics.

4. The comparison of creep resistance number $r_{s}$ characterizing the deformability of undisturbed and remoulded soils allows to quantify the structural sensitivity of soil subjected to uniaxial consolidation. Based on the analysis, the Krakowiec clay was classified as medium sensitive.

\section{References}

[1] Wheeler, S.J., Naatainen, A., Karstunen M. \& Lojander M. (2003). An anisotropic elastoplastic model for soft clays. Canad. Geotechn. Journ., 40 (2), 403-418.

[2] Gens, A. \& Nova R. (1993). Conceptual bases for a constitutive model for bonded soils and weak rocks. Geological Features, Investigation and Classification. Mechanical Properties and Behaviour, 1, 485-494.

[3] Grimstad, G., Degago, S. A., Nordal, S. \& Karstunen, M. (2010). Modelling creep and rate effects in structured anisotropic soft clays. Acta Geotechnica, 5, 69-81. doi: 10.1007/s11440-0100119-y.

[4] Røenningen, J. A., Gavel-Solberg, V. \& Grimstad G. (2014). Effective stress model for soft Scandinavian clays. European Young Geotechnical Engineers Conference, (pp. 1-4), Barcelona, Spain.

[5] Leroueil L. \& Vaughan, P. R. (1993). The general and congruent effects of structure in natural soil and weak rocks. Géotechnique, 40(3), 467-488.

[6] Janbu, N. (1969) The resistance concept applied to deformations of soils. 7th International Conference Soil Mechanics Foundation Engineering, Vol. 1, August 1969, (pp.191-196). Mexico city.

[7] Bjerrum, L. (1967). Engineering geology of norwegian normally-consolidated marine clays as related to settlements of Buildings. Géotechnique, 17:(83), 81-118, doi: 10.1680/geot.1967.17.2.83. 
[8] Ladd, C. C., Foott, R., Ishihara, K., Schlosser, F. \& Poulos, H. G. (1977). Stress - deformation and strength characteristics. State of the art report. International Conference on Soil Mechanics and Foundation Engineering, 9th, 1977, (pp. 421-494). Tokyo, Japan.

[9] Degago, S. A., Grimstad, G., Jostad, H. P. \& Nordal, S. (2009) The non-uniqueness of the end-of-primary (EOP) void ratioeffective stress relationship. Proc. 17th ICSMGE, 1, (pp. 324327). Alexandria, Egypt.

[10] Degago, S. A., Grimstad, G., Jostad, H. P. \& Nordal, S. (2013). Misconceptions about experimental substantiation of creep hypothesis A. Proceedings of the 18th International Conference on Soil Mechanics and Geotechnical Engineering, Paris, France.

[11] Nash, D. \& Brown, M. (2013). Influence of destructuration of soft clay on time-dependent settlements: comparison of some elastic viscoplastic models. International Journal of Geomechanics, 15(5), [A4014004]. DOI: 10.1061/(ASCE)GM.19435622.0000281.

[12] Tavenas, F. S., Leroueil, S., Rochelle, P. L. \& Roy M. (1978). Creep behaviour of an undisturbed lightly overconsolidated clay. Canadian Geotechnical Journal, 15(3), 402-423.

[13] Grimstad, G. \& Degago S. A. (2010). A Non-associated creep model for structured anisotropic (n-SAC). Numerical Methods in Geotechnical Engineering (NUMGE 2010), Taylor \& Francis Group, London, England. doi: 10.1201/b10551-1.

[14] Bjerre J. (2015). Development and evaluation of an effective stress based model for soft clays. Ph.D. thesis, Norwegian Univ. of Science and Technology, Trondheim.

[15] Karlsson M., Yannie J. (2016). Implementation of a modified anisotropic creep model with structure. Proceedings of the 2016 COMSOL Conference in Munich (2016) for soft soils with the Use of COMSOL. Physics Builder.
[16] Havel F., Creep in soft soils. Ph.D. thesis, Norwegian University of Science and Technology, Tronheim , Norway, 2004.

[17] Olek B.S. Woźniak H., 2017 - Wyznaczanie parametrów pełzania w konstytutywnym modelowaniu gruntów spoistych. Przegląd Geologiczny, 65(10): 873-882.

[18] Claesson, P. (2003). Long term settlements of clays. Ph.D. thesis, Chalmers University of Technology, Götheborg, Sweden.

[19] Grimstad G., Karstunen M., Jostad H.P., Sivasithamparam N., 40 Mehli M, Zwanenburg C., Haan E., Amri S.A.G., Boumezerane D., Kadavir M., Ashrafi M.A.H., Ronningen J.A. (2017). Creep of geomaterials - some finding from the EU project CREEP. European Journ. of Environmental and Civil Engineering: 1-16, http: //dx.doi.org/10.1080/19648189.2016.1271360.

[20] Cotecchia, F., \& Chandler, R. J. (2000). A general framework for the mechanical behaviour of clays. Géotechnique, 50(4), 431447.

[21] Burland, J. B. (1990). On the compressibility and shear strength of natural clays. Géotechnique, 40(3), 329-378.

[22] Rosenqvist I., 1953 - Considerations on the sensitivity of norwegian quick-clays. Géotechnique, 3(5) 195-200

[23] Olesiak S. 2010 - Sonda wkręcana WST w badaniach mioceńskich iłów krakowieckich. Górnictwo i Geoinżynieria, nr 2/2010, 501-507.

[24] Olesiak S. 2014 - Ocena stopnia plastyczności iłów mioceńskich na podstawie badań sondą wkręcaną WST. Inżynieria Morska i Geotechnika, nr 2/2014

[25] Pilecka E., Zięba J. 2016 - Zachowanie się iłów mioceńskich jako podłoża gruntowego planowanych inwestycji transportowych Krakowa. Autobusy: technika, eksploatacja, systemy transportowe, 12. 387 - 391. 